\title{
Mischocyttarus (Kappa) santacruzi, a new species of social wasp (Hymenoptera, Vespidae) from Eastern Brazilian wet forest ${ }^{1}$
}

\section{Anthony Raw ${ }^{2}$}

\begin{abstract}
The holotype female, allotype male and nest are described of a new species of social wasp, Mischocyttarus (Kappa) santacruzi (Hymenoptera, Vespidae) from Atlantic coastal forest, Bahia, State, eastern Brazil. Morphologically the species is close to $M$. (Kappa) adolphi Zikán.

KEY WORDS. Hymenoptera, Vespidae, Mischocyttarus, social wasp, Brazil, Atlantic forest
\end{abstract}

\section{Mischocyttarus (Kappa) santacruzi sp.n.}

Holotype female. Length $12.9 \mathrm{~mm}$. Length of fore wing $9.7 \mathrm{~mm}$. Insect largely black. Clypeus, frons up to height of two ocellar diameters from anterior ocellus, antennal scape, lower corner of pronotum, patch on dorsal area of mesepisternum and proximal half of fore tibia orange-brown. Mandibular teeth, extreme apical margin of clypeus, venation and legs (except coxae and fore femur) dark brown. Yellow areas are genal stripe along entire length of orbit including malar space, pronotal carina, hind margin of pronotum, spot on posterior side of tegula, stripe along posterior side of axilla, metanotum except large posterior diamond, triangle at posterior margin of propodeum outside insertion of propodeal valve, stripe on outer side of mid and hind coxae, all knees, subapical margins of first and second metasomal tergites. Transparent parts are propodeal valve and extreme apex of first and second metasomal tergites. Subapical band of first tergite wider than that of second and very slightly interrupted centrally. Subapical band of second tergite extremely narrow. Last fore tarsomere with narrow white stripe. Larger hind tibial spur dark brown except pale brown tip, smaller spur pale brown.

Clypeus wider than high (100:87), very slightly convex and flattened centrally, angled below and slightly rounded at apex, its sides touching eye for $1.5 \mathrm{X}$ the diameter of an antennal socket. The apical margin slightly wavy. Punctures small and contiguous over the dorsal half of clypeus, slightly less dense and mixed with larger punctures towards apex. Apical part below forward mandibular insertion flattened and impunctate though minutely granular. Ocelli forming right-angled triangle, the anterior ocellus separated from a lateral ocellus by one ocellar diameter. Occiput weakly margined, stronger laterally. Width of gena at its mid point slightly less than half width of eye. Forward condyle almost touching eye. Frons densely but finely punctured. Mandible quadridentate, the inner tooth rounded and with a sharp upper corner; the others sharp.

1) Work financed by the Projeto RestaUna, Ilhéus, Bahia.

2) Departamento de Ciências Biológicas, Universidade Estadual de Santa Cruz. 45650-000 Ilhéus, Bahia, Brasil. 
Scape of antenna $0.78 \mathrm{~mm}$ long and $0.27 \mathrm{X}$ maximum width of head. Pronotal keel straight in dorsal view, interrupted along central $30 \%$ of length, quite strong laterally, ending abruptly and not extended downward, lateral lobes present but small. Anterior margin of pronotum recurved; the hind margin of furrow behind it acute but not raised. Pronotal fovea opening to a short downward groove, without carina in front of it. Dorsal groove of mesepisternum and scrobal furrow present. Mesoscutum, scutellum, black part of metanotum, mesepisternum and upper part of propodeum finely punctured; the interstices less than a puncture diameter and granulate. Yellow part of metanotum more shining and with fewer punctures. Mesopleuron and lower part of propodeum with finer and coarser punctures. Central furrow of propodeum long, moderately deep and with a central keel along almost entire length. Opening of muscle slit narrower; propodeal valves very low and transparent. Third and fourth tarsal segments of mid and hind legs strongly assymetrical. Larger claw of hind leg thickened and blunter than smaller claw. First metasomal tergite gradually expanded posteriorly, its posterior margin $2.2 \mathrm{X}$ width of the base, and the anterior width $1.8 \mathrm{X}$ its length (measured from the posterior side of ligamentary aperture). Almost entire surface of insect with scattering of silvery, short, subappressed hairs. Lower part of clypeus and mandible with sparse, short erect hairs. Fore coxa with pile of long silvery hairs reminiscent of Agelaia Lepeletier, 1836.

Allotype male. Length $12.6 \mathrm{~mm}$. Length of fore wing $9.2 \mathrm{~mm}$. General colouration as the female, but with the following differences. Tegula entirely dark brown. Ochre on apical half of mandible except teeth, suffusion in ocular sinus extending downward to clypeus, inner side of seven apical segments of antenna, anterior side of fore and mid coxa, patch on anterior part of pleuron, stripe on fore side of fore tibia and mid and hind femur, and triangle on forward part of scutellum (except narrow central line).

Clypeus higher than wide (ratio 10:9), flattened, apical margin shallowly angled below at apex, covered in appressed silvery pile and bearing sparse punctures, its sides touching eye for $2 \mathrm{X}$ the diameter of an antennal socket. Antenna curled at apex, the four apical segments much narrower than proximal ones, apical segment $3 \mathrm{X}$ its basal width and pointed at tip. Aedeagus a narrow tube slightly widening apically. Ventral serrations of aedeagus extending from near tip to its ventral process. Gonobase narrow. Gonocoxite narrow and widening gradually, with row of fine hairs on inner side below cuspis. Digitus of volsella with small, strong, black backward-facing hook. Gonostylus tapering gradually, darker subapical part of gonostylus bearing long, fine hairs on dorsal surface and extending on both sides to ventral surface. Spine of gonostylus spinelike and protruding, bearing a few hairs.

Type locality. The site lies $1.6 \mathrm{~km}$ south-west of the administrator's house

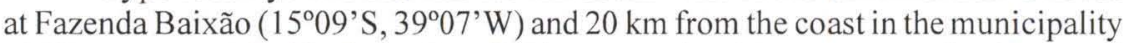
of Ilheus, eastern Bahia State, Brazil. The vegetation is evergreen Atlantic coastal forest with an unbroken canopy $17 \mathrm{~m}$ to $22 \mathrm{~m}$ tall. The wasps and nest were collected on 12 February 1999.

Type material. The holotype female and allotype male are deposited in the Museu de Zoologia de São Paulo. Paratype females and males are deposited in the author's collection, the Museu Emílio Goeldi in Belém, Oxford University Museum and the Smithsonian Institution in Washington, DC.

Revta bras. Zool. 17 (4): 941 - 943, 2000 
The nest. The one nest which was discovered was attached $155 \mathrm{~cm}$ from the ground to a node of a vine which was $2.5 \mathrm{~mm}$ thick at that height. The thin, leafless vine extended $15 \mathrm{~m}$ from near the canopy to the ground. The nest was suspended horizontally from a short central peduncle. The carton was streaked mid and pale brown and very fragile. The nest was $83 \mathrm{~mm}$ long and $12.5 \mathrm{~mm}$ wide at its maximum. The comb comprised 39 cells. It was three cells wide along the central portion of five cells and the two ends of six and seven cells were two cells wide - each $4.6 \mathrm{~mm}$ wide. There were eight closed cocoons $12 \mathrm{~mm}$ long. Of the open cells, six contained an egg, nine contained a larva and two bore remnants of the cocoon cap around the rim. The cap of the cocoon was hemispherical, semi-transparent and attached to the rim of the cell. Seven adult females were present on the nest during two hours. Two females and four males emerged from the closed cocoons.

The species group. Morphologically $M$. santacruzi is close to $M$. adolphi Zikán, 1935 (Manaus and Óbidos, northern Pará State), M. frontalis (Fox, 1894) (Mato Grosso and Goias States) and M. anthracinus Richards, 1945 (Paraguay) (see RICHARDS 1978: 289). Viewed from above the profile of the propodeal furrow can be compared with that of the adjacent shoulders. In M. adolphi and M. frontalis the depression is clearly wider than the convexity of a shoulder, whereas in $M$. anthracinus and $M$. santacruzi the convavity of the propodeal depression matches the convexity of a shoulder. In addition to the characters listed in table I, M. santacruzi differs from the three others in bearing longer denser hairs on the fore coxa and a yellow band on the first metasomal tergite. $M$. adolphi differs from the others in bearing a yellow band on the second, third and fourth metasomal tergites and sternites. M. anthracinus differs from the others in replacing many of the yellow markings with reddish brown.

The name of the wasp refers to Santa Cruz, the local name for the southern part of the State of Bahia.

Table I. Characters to distinguish the females of four similar Mischocyttarus species.

\begin{tabular}{lllll}
\hline & M. adolphi & M. frontalis & M. anthracinus & M. santacruzi \\
\hline Propodeal furrow * & Wider & Wider & Narrower & Narrower \\
Dorsal part of mesipsternum & Yellow & Yellow & Black & Brown \\
Pleural punctures & Fine and coarse & Only fine & Only fine & Fine and coarse \\
\hline
\end{tabular}

*) See text for explanation.

ACKNOWLEDGEMENTS. I am grateful to Mr. Helfred Hess for permission to collect biological specimens on his property. The material was collected while the author held a visiting research fellowship at the Universidade Estadual de Santa Cruz, Ilheus, Bahia, on grant number 300580/84-3 of the Conselho Nacional de Desenvolvimento Científico e Tecnológico (CNPq). The present work is a part of the Projeto RestaUna financed by the Programa de Biodiversidade ( $\mathrm{PRONABIO} / \mathrm{PROBIO}$ ) of the Ministério do Meio Ambiente, with the support of CNPq, the Global Environmental Facility and World Bank (BIRD).

\section{REFERENCE}

Richards, O.W. 1978. The Social Wasps of the Americas. London, British Museum (Natural History), 580 p.

Recebido em 17.VI.1999; aceito em 19.X.2000 